\title{
Pasientrettigheter - jus og fag
}

Fordeling av helsetjenester foregår i et samspill mellom politisk og økonomisk styring, medisinsk skjønn og juridisk kontroll. Rettighetsfesting endrer dynamikken i dette samspillet ved at den juridiske kontrollen blir forsterket ved klagesaker og saker for domstolene. Rettighetsfesting forutsetter som regel presise kriterier for å fungere godt. I helsetjenesten er det vanskelig å utforme rettigheter på en presis måte. Det fremstår riktignok som greit å regulere legers atferd i møtet med pasienter, for eksempel gjennom krav til journalføring og pasienters rett til informasjon. Krav til klinisk virksomhet vil lettere bære preg av «rettslige standarder» der faglige og yrkesetiske vurderinger kommer inn ved vurderingen av om kravet er brutt. Dette gjelder blant annet «forsvarlighetskravet» til legers opptreden. Etter helsepersonelloven $\S 4$ skal arbeidet utføres «i samsvar med de krav til faglig forsvarlighet og omsorgsfull hjelp som kan forventes ut fra helsepersonellets kvalifikasjoner, arbeidets karakter og situasjonen for øvrig». Enda vanskeligere kan det være å fastlegge hva som ligger i bestemmelser som gir rett til helsehjelp, som for eksempel pasient- og brukerrettighetsloven $\S 2-1 \mathrm{~b}$, som fastslår at «[p]asienten har rett til nødvendig helsehjelp fra spesialisthelsetjenesten».

Det har vært lettere å vedta bestemmelser som gir rett til bestemte ytelser og stønader på andre områder i velferdsretten. Mens enkelte trygdeytelser utløses av faktumstyrte bestemmelser uten bruk av skjønn, som foreldrepenger ved fødsel og dagpenger ved arbeidsløshet, må det utøves skjønn ved tildeling av uføretrygd. Trygderettighetene fikk, etter en sped start i 1894 ved loven om ulykkesforsikring for fabrikkarbeidere, flere ekspansjonsfaser i mellomkrigstiden før folketrygdloven kom på plass i 1966 (1). En alminnelig skolerett og -plikt i en samlende enhetsskole ble lovfestet allerede ved folkeskolelovene av 1889, mens barn som var oppfattet som ikke-opplæringsdyktige ikke ble omfattet før i 1960-årene (2). De første landsomfattende fattiglovene ble gitt i 1845 og 1863, men rettighetspreget ble først vesentlig styrket gjennom etterkrigstidens sosiallover (lov om sosial omsorg 1964, sosialtjenesteloven 1991). Rettsliggjøringen på det velferdsrettslige området ble altså konsolidert først i sen etterkrigstid.

I dette nummer av Tidsskriftet foretar Leif Arne Heløe et spennende sveip gjennom norsk sosialhistorie og norsk sosialrett gjennom de siste 150 år under overskriften Fra paternalisme til pasientrettigheter (3). Men han tilskriver pasientrettighetsloven av 1999 for stor betydning når han hevder at paternalismen først da fikk «sitt grunnskudd når det gjelder medisinsk behandling». Riktigere er det nok at 1999-loven kodifiserte «gjeldende rett» på de områdene som da ble regulert (4). En rett til informasjon, et krav om (informert) samtykke og rett til innsyn i egen pasientjournal var for eksempel allerede avklart gjennom konkrete høyesterettsavgjørelser.

Pasientrettigheter var også avklart gjennom overordnede normer. Med bakgrunn i erfaringer fra den annen verdenskrig ble det i FNs konvensjon om sivile og politiske rettigheter fastslått at «ingen [skal], uten sitt frie samtykke, utsettes for medisinske eller vitenskapelige eksperimenter». Retten til helse er nedfelt i FNs konvensjon om økonomiske, sosiale og kulturelle rettigheter: «Konvensjonspartene anerkjenner retten for enhver til å ha den høyest oppnåelige helsestandard både i fysisk og psykisk henseende.» Begge de nevnte 1966-konvensjonene ble inkorporert i norsk rett gjennom menneskerettsloven i 1999, og før pasientrettighetsloven ble gitt.
Heløe er kritisk til rettsliggjøringen av faglige avgjørelser, men det er vel lite gjenværende motstand i legekretser mot pasienters rett til innsyn i journal, muligheter for å påklage helsepersonells opptreden og en viss rett til medvirkning basert på adekvat informasjon. Det nevnte forsvarlighetskravet understøtter for øvrig legers faglige autonomi, idet en lege ikke har rett til å gjennomføre uforsvarlige behandlingsinngrep uansett hvor etterspurt de måtte være fra pasientens side.

Kravet om flere regler og retningslinjer kommer i begrenset utstrekning utenfra. Det er fagfeltet selv som ofte føler behov for en faglig og juridisk trygghet, særlig ved arbeid på etisk utfordrende områder som behandlingsbegrensninger ved livets slutt. Men Helsedirektoratet utarbeider også retningslinjer på mange andre områder, som for eksempel om diagnostisering og oppfølging av personer med kols, om utredning og behandling av bipolar lidelse og om svangerskap, fødsel og barseltid, for bare å nevne noen. I de sentrale helselovene er Helsedirektoratet fra 1.1. 2012 gitt myndighet til å utarbeide nasjonale veiledere og retningslinjer, se spesialisthelsetjenesteloven $§ 7-3$. Slike retningslinjer vil - som de 33 prioriteringsveilederne for spesialisthelsetjenestens vurderinger av «nødvendig helsehjelp» - i stor utstrekning styre legers vurderinger, uavhengig av styrken på den tilgrunnliggende rettslige forankringen.

Det foreligger i større grad en selvjustis innen legestanden - ut fra kravet om likebehandling - enn en egentlig rettsliggjøring av klinisk virksomhet. Men det finnes i pasientrettighetsloven bestemmelser som griper rett inn i lege-pasient-forholdet ved en utvilsom plikt til å informere og et krav om samtykke før undersøkelse og behandling. Det er likeledes skjedd en tydeliggjøring av hvem som kan samtykke - eller ta beslutninger - når pasienten selv er ute av stand til dette, enten det skyldes mindreårighet, kognitiv svikt, bevisstløshet eller andre grunner.

Bestemmelser som gir pasienter rett til ulike former for helsetjenester, for eksempel «rett til nødvendig helsehjelp», fører lett til problemer med forskjellsbehandling når skjønnsmessige og faglige vurderinger skal knyttes opp mot en vagt utformet lovtekst. Dette var bakgrunnen for prioriteringsprosjektet, som skulle operasjonalisere kravene i lov og forskrift ned mot den enkelte legespesialitet. Dette arbeidet ble verken initiert eller gjennomført som et juridisk prosjekt, men som et fagprosjekt. I prioriteringsveilederne er selve lovteksten knapt omtalt og vurdert, det er diagnostisering og særtrekk ved den enkelte pasients tilstand som naturlig nok står i sentrum. Forholdet mellom jus og fag er altså mer fasettert enn helsepersonell ofte legger til grunn.

\section{Aslak Syse \\ asyse@jus.uio.no}

Aslak Syse (f. 1946) er professor dr.juris., lege og instituttleder ved Institutt for offentlig rett, Universitetet i Oslo.

Ingen oppgitte interessekonflikter.

Litteratur

. Kjønstad A. Innføring i trygderett. 4. utg. Oslo: Universitetsforlaget, 2009.

2. Syse A. Rettssikkerhet og livskvalitet for utviklingshemmede. 2. utg. Oslo: Ad Notam Gyldendal, 1996.

3. Heløe LA. Fra paternalisme til pasientrettigheter. Tidsskr Nor Legeforen 2012; 132: 434-6.

4. Syse A. Pasientrettighetsloven med kommentarer. 3 utg. Oslo: Gyldendal Akademisk, 2009 